\title{
Moderated milk replacer restriction of ewe lambs alters gut immunity parameters during the pre-weaning period and impairs liver function and animal performance during the replacement phase
}

\author{
J. Frutos"a, S. Andrés ${ }^{\mathrm{a}, *}$, E. Trevisi ${ }^{\mathrm{b}}$, J. Benavides ${ }^{\mathrm{a}}$, N. Santos ${ }^{\mathrm{a}}$, A. Santos ${ }^{\mathrm{a}}$, F. J. \\ Giráldez $^{\mathrm{a}}$
}

${ }^{a}$ Instituto de Ganadería de Montaña, CSIC-Universidad de León, Finca Marzanas s/n, 24346, Grulleros, León (Spain). jdefrutos@igm.csic.es, sonia.andres@eae.csic.es, julio.benavides.silvan@csic.es, n.santos@csic.es, alba.santos@igm.csic.es, j.giraldez@eae.csic.es

${ }^{b}$ Department of Animal Sciences, Food and Nutrition (DIANA), Università Cattolica del Sacro Cuore. Via Emilia Parmense 84, 29122, Piacenza (Italy). erminio.trevisi@unicatt.it

*Corresponding author at: Instituto de Ganadería de Montaña, CSIC-Universidad de León, Finca Marzanas s/n, 24346, Grulleros, León (Spain).

E-mail address: sonia.andres@eae.csic.es (S. Andrés).

1

\footnotetext{
${ }^{1}$ Abbreviations: ADL, ad libitum; AST, aspartate aminotransferase; BHB, beta-hydroxybutyrate; Cq, quantification cycle; FRAP, ferric reducing ability of plasma; GALT, gut-associated lymphoid tissue; GGT, gamma glutamyl transpeptidase; HDL, high-density lipoprotein; IFN- $\gamma$, interferon gamma; IL, interleukin; iPP, ileal Peyer's patches; LBW, live body weight; LDL, low-density lipoprotein; MR, milk replacer; NEFA, non-esterified fatty acids; PEM, protein-energy malnutrition; PON, paraoxonase; RES, restricted; ROM, reactive oxygen metabolites; SED, standard error of the difference; sIgA, secretory immunoglobulin A; SOD, superoxide dismutase; TGF- $\beta$, transforming growth factor beta; TLRs, toll-like receptors; TMR, total mixed ration.
} 


\section{ABSTRACT}

Undernutrition during the first stages of life may impair maturation of the immune system, harming the health status permanently. Thus, the aim of the present study was to define the impact of moderated milk replacer (MR) restriction during the artificial rearing period on the gut-associated lymphoid tissues of pre-weaned ewe lambs and long-term effects on biochemical profile and animal performance during the replacement period. Forty female Assaf lambs [average live body weight (LBW) $4.73 \pm$ $0.116 \mathrm{~kg}$ ] were penned individually. The first group of lambs $(\mathrm{n}=20)$ was fed MR $a d$ libitum (ADL) whereas the second one (restricted, RES; $\mathrm{n}=20$ ) only received approximately $62.5 \%$ of the MR intake measured in the ADL group. All the lambs were weighed twice a week until they were 35-days-old. Then, 8 lambs from each group (preweaned) were harvested and ileal samples collected. The rest of the lambs (12 ADL vs. 12 RES) were weaned progressively, and then offered a total mixed ration (TMR) ad libitum until the end of the experiment (7.5-months-old). The lower nutrient intake of RES pre-weaned lambs caused greater percentages for $\mathrm{T}$ lymphocytes $\left(\mathrm{CD} 4^{+}, \mathrm{CD} 8^{+}\right.$, $\mathrm{WC}^{+}$) and an increased secretory immunoglobulin A ( $\left.\operatorname{Ig} \mathrm{A}\right)$ production in the ileum compared to the ADL group $(P<0.05)$. These results, together with the significant differences in the expression of toll-like receptors and cytokines at this level (e.g., interferon gamma was increased in the RES group; $P<0.05)$ suggest the existence of pro-inflammatory conditions in the ileum of pre-weaned lambs promoted by early feed restriction. Moreover, the biochemical profile revealed that liver function (e.g., albumin, gamma glutamyl transpeptidase) was impaired during several months once the feed restriction period was finished, whereas the average daily gain during the replacement phase was reduced for the early feed restricted lambs (182 vs. $202 \mathrm{~g} / \mathrm{day}$ for RES and ADL groups, respectively; $\mathrm{P}<0.05)$. Therefore it can be concluded that moderated $\mathrm{MR}$ 
restriction promoted both, pro-inflammatory conditions at ileal level in the pre-weaned lambs and an altered liver function which lasted several months after the end of feed restriction. Both circumstances might have impaired animal performance during the replacement phase of the ewe lambs.

Key words: feed restriction, metabolic programming, feed efficiency, inflammation, microbiome, GALT

\section{Introduction}

Nutrition is a critical determinant of immune response, so a deficient supply of nutrients may influence cell-mediated immunity, cytokine production, the complement system, phagocytic functions and secretory immunoglobulin $\mathrm{A}(\operatorname{sg} \mathrm{A})$ concentrations in humans according to the review reported by Chandra (1997). These effects can be worsened if feed restriction takes place during early life, because the lack of nutrients may impair not only animal growth, but also the adequate development of the gutassociated lymphoid tissue (GALT), thus having negative consequences on the health status along the whole life. Moreover, there is a complex interplay between nutrients, bacteria attached to the intestinal mucosa (epimural bacterial community) and the epithelial barrier of the GALT which plays a crucial role in the maturation of the

immune system during the first months of life (Celi et al., 2017), so any factor modifying the colonization of the gut may also have long-term consequences on the health of the animals. However, even though there are several evidences in both humans and laboratory animal models (Chandra, 1997) and a recent experiment has described the effects on newborn calves (Schäff et al., 2016), to our knowledge there are no studies explaining the short and long-term effects of milk replacer (MR) restriction on GALT immunity and biochemical parameters of artificial reared ewe lambs. Extending 
the knowledge about the mechanisms underlying nutritional programming by early feed restriction is crucial, since this circumstance -which may take place in the farm as a consequence of environmental, health or non-optimal feeding conditions- may affect the health status and animal performance of the animals along the whole life, thus decreasing the profitability of the dairy farm (e.g., reduced milk production or delay in the onset of puberty).

Therefore, the aim of the current study was to investigate the impact of moderated MR restriction on replacement dairy ewe lambs. Our working hypothesis was that early feed restriction during the artificial rearing period influences negatively GALT development, promoting gut inflammation and long-lasting changes on biochemical profile and animal performance of ewe lambs during the replacement phase.

\section{Material and methods}

\subsection{Care and Use of Animals}

All handling practices involving animals followed the recommendations of the Directive 2010/63/EU of the European Parliament and of the Council on the protection of animals used for scientific purposes and the IGM-CSIC Animal Experimentation Committee (protocol number 2015-04).

\subsection{Animals and milk replacer during the artificial rearing period}

A flock of newborn Assaf lambs was separated from their dams just after parturition. The dams were hand-milked and the colostrum offered to the lambs by bottle-feeding for 2 d. Lambs were bottle-fed for another $2 \mathrm{~d}$ with commercial MR (200 g dry matter/L) (Cordevit, Leches Maternizadas S.A., León, Spain). All newborn lambs were 
treated with an intramuscular injectable selenium + vitamin E complex at the prescribed dose (Vitasel: $5 \mathrm{~g} \alpha$-tocopherol acetate, $110 \mathrm{mg}$ sodium selenite, excipient, per $100 \mathrm{ml}$; Laboratorios Ovejero, León, Spain) to prevent nutritional muscular dystrophy (white muscle disease). Thereafter, 40 female lambs were selected from the flock to minimise the range of both, live body weight (LBW) and day of birth. Subsequently, all the lambs were stratified on the basis of LBW (on average $4.73 \pm 0.116 \mathrm{~kg}$ ), penned individually, and allocated randomly to one of two treatment groups $(n=20$ per treatment). All the lambs were fed MR three times daily (8:30, 14:00 and 20:30 hours) during the first week, and only twice daily (08:30 and 19:30 hours) during the rest of the suckling period. However, whilst the first group of lambs was fed MR ad libitum (ADL, approx. 2.5 times maintenance energy requirements to gain $250 \mathrm{~g} /$ day), the second one (restricted, RES) only received approximately $62.5 \%$ of MR intake measured in the ADL group (approx. 1.5 times maintenance energy requirements to gain 100-120 g/day) (NRC, 1985; Giráldez et al., 1999). A bucket with a teat was used to fed each lamb, being removed 20 minutes later when the lambs either had finished the offered MR or stopped eating because they were satisfied. All the lambs were weighed twice a week throughout the suckling period and the average daily weight gain (ADG, g/d) was estimated as the regression coefficient (slope) of LBW against time using the REG procedure of the SAS package (SAS Inst. Inc., Cary, NC). Ingredients and chemical composition of the MR administered are summarized in Table 1.

[INSERT TABLE 1 NEAR HERE, PLEASE]

\subsection{Slaughter procedure and ileal parameters of pre-weaned lambs}

When lambs were 35-days-old, eight lambs from each group (16 lambs in total) were stunned and harvested by exsanguination from the jugular vein, eviscerated and skinned 
according to the Council Regulation (EC) $\mathrm{N}^{\circ} 1099 / 2009$ on the protection of animals at the time of killing. Total fat depots (omental, mesenteric and perirenal) were separated and weighed. Additionally, and immediately after slaughter, $2 \mathrm{~g}$ of ileal contents were collected in two different tubes $(10 \mathrm{ml}$ each) containing $6 \mathrm{ml}$ of distilled water and 0.25 $\mathrm{mL}$ of $20 \%$ sulfuric acid solution to acidify the medium and stop the fermentation. Fermentation end-products (volatile fatty acids) were determined according to Carro and Miller (1999). A $10 \mathrm{~cm}$ segment of ileum from each animal was collected proximal to the ileocecal valve immediately after slaughter. Ileal samples were rinsed three times with sterile phosphate-buffered saline solution $(\mathrm{pH}=7.0)$ to remove the digesta and divided into several portions preserved in different ways for analysis of epimural bacterial community (stored at $-80^{\circ} \mathrm{C}$ during 48 hours, then freeze-dried), flow cytometry (sterile phosphate-buffered saline solution), histological or immunohistochemical examination (fixed by immersion in $10 \%$ buffered formalin for one week), sIgA quantification (stored at $-20^{\circ} \mathrm{C}$ ), and gene expression of cytokines and toll-like receptors [stabilized with $\mathrm{RNA}_{\text {later }}$ (Invitrogen, Carlsbad, CA, USA) overnight at $4^{\circ} \mathrm{C}$, and stored at $-80^{\circ} \mathrm{C}$ ]. Ileal epimural microbiota was assayed by DNA extraction and quantitative real-time PCR (qPCR); sIgA quantification in ileal mucosa was determined by ELISA; gene expression of cytokines and toll-like receptors was performed by RNA extraction of ileal samples and real-time reverse transcription PCR; all these procedures (assessed in duplicate for each parameter and lamb), together with flow cytometry (assayed in a single ileal sample per lamb), histological or immunohistochemical techniques (ten different fields were examined per parameter and lamb) performed on ileal samples were carried out according to Frutos et al. (2018a). 


\subsection{Animal performance and biochemical profile of replacement ewe lambs}

The rest of the ADL ewe lambs $(n=12)$ were weaned progressively starting at a mean LBW of $13.5 \mathrm{~kg}(\mathrm{ADL})$, whereas the RES ewe lambs $(\mathrm{n}=12)$ started weaning either with $11.5 \mathrm{~kg}$ or 70-days-old in order to ensure the viability of the lambs, but reducing at the same time the differences in age or weight at weaning. The progressive weaning lasted one week for each lamb and consisted in restricting MR intake and allowing free access to a starter feed for replacement lambs (Babymix, Inatega, León, Spain), barley straw and alfalfa hay. After weaning, the lambs were moved to a single feedlot for 42 days ( $1^{\text {st }}$ post-weaning period), and fed ad libitum the same starter feed, barley straw and alfalfa hay supplied in separate feeders. After this period, the ewe lambs were fed ad libitum a total mixed ration (TMR) in feedlot until the end of the experimental period (7.5-months-old). All the ewe lambs were weighed once a week during the replacement period and the ADG during this phase estimated as previously mentioned.

Samples of the TMR offered were collected weekly and analysed for dry matter (ISO 6496:1999), ash (ISO 5984:2002), crude protein (ISO 5983:2009), aNDF (NDF was assayed with a heat stable amylase and expressed inclusive of residual ash; Ankom Technology Corp., Macedon, NY, USA) and ADF (ADF was expressed inclusive of residual ash; Ankom Technology Corp., Macedon, NY, USA). Ingredients and chemical composition of the TMR administered are summarized in Table 2.

\section{[INSERT TABLE 2 NEAR HERE, PLEASE]}

The 24 ewe lambs (12 animals per group) were blood sampled three times along the experiment early in the morning, at the end of the feed restriction period ( $1^{\text {st }}$ month) or 
once the replacement ewes were being fed exclusively the experimental TMR ( 5 and 7.5 months-old). Blood samples were collected by jugular venipuncture into tubes containing lithium-heparin, placed in iced water and centrifuged at $3520 \times \mathrm{g}$ for $16 \mathrm{~min}$ at $5^{\circ} \mathrm{C}$. Plasma samples were stored at $-80^{\circ} \mathrm{C}$ until biochemical profile analysis.

Plasma samples were analysed for haptoglobin, ceruloplasmine, betahydroxybutyrate (BHB), paraoxonase $(\mathrm{PON})$, reactive oxygen metabolites (ROM), myeloperoxidase, ferric reducing ability of plasma (FRAP), superoxide dismutase (SOD), $\mathrm{Ca}, \mathrm{Mg}, \mathrm{Zn}$, retinol, tocopherol, aspartate aminotransferase (AST), gamma glutamyl transpeptidase (GGT), total bilirubin, creatinine, glucose, insulin, urea, protein, albumin, globulin, cholesterol, low-density lipoprotein (LDL), high-density lipoprotein (HDL), non-esterified fatty acids (NEFA) and triglycerides as described by Frutos et al. (2018b). Globulin was calculated as the difference between total protein and albumin. Moreover, insulin, specific for sheep, was measured using ELISA assay (Mercodia Ovine Insulin ELISA, Uppsala, Sweden) in microplates (Synergy 2, BioTek, Winooski, VT, USA). Plasma vitamins A and E were measured by extraction with hexane and reverse-phase high-performance liquid chromatography using Spherisorb ODS-2, $3 \mathrm{~m}$, in a $150 \times 4.6 \mathrm{~mm}$ column (Alltech, Deerfield, IL, USA); an ultraviolet/visible detector set at $325 \mathrm{~nm}$ (for vitamin A) or $290 \mathrm{~nm}$ (for vitamin E); and 80:20 methanol:tetrahydrofurane as the mobile phase.

\subsection{Statistical analysis}

Average daily gain data, together with those of total fat depots, intestinal fermentation parameters, quantification of epimural bacterial community, flow cytometry, morphometric analysis, immunohistochemistry, sIgA quantification and gene expression of toll-like receptors (TLRs) and cytokines were analyzed by one-way 
ANOVA using the GLM procedure of SAS (SAS Institute Inc., Cary, North Carolina) with the dietary treatment (ad libitum or restricted during the artificial rearing phase) as the only source of variation. In all cases, the individual lamb was considered as the experimental unit. Significance was declared at $P<0.05$ and a tendency at $P<0.1$.

Data corresponding to biochemical parameters measured at several growth stages $\left(1^{\text {st }}, 5^{\text {th }}\right.$ and $7.5^{\text {th }}$ months of life of replacement ewe lambs $)$ were analyzed as a repeated measures design using the MIXED procedure of SAS. Dietary treatment and growth stage were included in the model (the main effects of both factors and their interaction) as fixed effects. In all cases, the individual lamb was considered as the experimental unit and included in the model as a random effect. For each variable, the statistical model was fitted with different competing covariance structures, selected with the smallest value for Akaike's and Bayesian criterions. The Tukey-Kramer multiplecomparison test was used to compare means when the interaction between dietary treatment and growth stage was significant.

\section{Results}

\subsection{Animal performance}

Both ADG during the artificial rearing period (116 vs. $237 \mathrm{~g} /$ day for the RES and ADL groups, respectively; $\mathrm{SED}=20.0 ; P<0.001)$ and the weight at weaning $(11.2 \mathrm{vs}$. $13.7 \mathrm{~kg} ; \mathrm{SED}=0.25 ; P<0.001)$ were lower in RES lambs due to MR restriction. Thereafter, a compensatory growth period for the RES ewe lambs (non-slaughtered) was observed after weaning (274 vs. 238 g/day for the RES and ADL lambs, respectively; $\mathrm{SED}=15.76 ; P<0.05)$, but the $\mathrm{ADG}$ was reduced for the early feed restricted lambs once all animals were being fed ad libitum the TMR during the 
replacement phase (182 vs. 202 g/day for RES and ADL groups, respectively; SED= $8.61 ; P<0.05)$. The LBW at the end of the experiment (7.5-months-old) was numerically lower for the RES ewe lambs, but no significant differences were detected (45.1 vs. 50.4 $\mathrm{kg} ; \mathrm{SED}=3.11 ; P>0.05)$.

\subsection{Ileal epimural bacterial community and volatile fatty acids of pre-weaned lambs}

No differences were observed for total bacteria or the relative abundance of Bifidobacterium spp. or Prevotella spp. in the ileal epimural bacterial community between experimental groups (ADL vs. RES lambs, Figure 1). Acetate measurements were lower in the RES group compared to the ADL lambs $(0.71$ vs. $1.42 \mathrm{mmol} / \mathrm{L}$; $P<0.05, \mathrm{SED}=0.242$ ). The rest of volatile fatty acids (e.g., propionate, butyrate...) were not detected.

\section{[INSERT FIGURE 1 NEAR HERE, PLEASE]}

\subsection{Ileal immunity parameters of pre-weaned lambs}

The results regarding the specific ileal lymphocyte population counts (flow cytometry), thickness of ileal layers (histologic examination), ileal M-cells labelling intensity, counts of infiltrating $\mathrm{B}$ or $\mathrm{T}$ lymphocytes in the ileal lamina propria (immunohistochemistry), and sIgA concentration in ileal mucosa (ELISA) are summarized in Table 3.

\section{[INSERT TABLE 3 AND FIGURE 2 NEAR HERE, PLEASE]}

Greater percentages for $\mathrm{T}$ lymphocytes $\left(\mathrm{CD}^{+}, \mathrm{CD}^{+}, \mathrm{WC}^{+}\right)$were detected in the ileum of the RES group when compared to the ADL lambs $(P<0.05)$. Moreover, morphometric analysis revealed a reduced thickness of ileal submucosa layer in the RES 
group $(P<0.05)$ where the ileal Peyer's patches (iPP) are located (Figure 2$)$. In addition, the infiltration of B-cells in the ileal lamina propria (Table 3, Figure 2) and the concentration of sIgA at ileal mucosa level were reduced $(P<0.05)$ and increased $(P<0.05)$, respectively in the RES lambs. On the contrary, the infiltration of T-cells in the ileal lamina propria (Table 3, Figure 2) was not affected significantly by early feed restriction, but numerically higher values could be observed for the RES lambs (204 vs. 176 cells per filed 40x). Also, a trend towards significantly higher percentages $(P<0.1)$ of negatively labelled regions in the epithelium region of the iPP domes was observed when M-cell marker was assessed in the RES group (Table 3, Figure 2). This was corroborated by the H-index for M-cell, which tended to be lower in the RES group $(P<0.1)$

Cytokines and TLRs gene expression at the ileal tissue (including iPP) is shown in Table 4. The mRNA expression of interferon gamma (IFN- $\gamma$ ) was greater in the RES group $(P<0.05)$ whereas transforming growth factor $\beta($ TGF- $\beta ; P<0.05)$ and interleukin 10 (IL-10, $P<0.05$ ) were down-expressed in these lambs (a smaller $\Delta \mathrm{Cq}$ value equates to more abundant transcript). Also, interleukin 4 (IL-4, $P<0.1$ ) showed a trend towards significantly lower values in the RES lambs. In addition, gene expression of several TLRs was significantly down-regulated in the early feed restricted group (e.g., TLR-1, TLR-6, TLR-7, TLR-9; $P<0.05)$.

\section{[INSERT TABLE 4 NEAR HERE, PLEASE]}

\subsection{Biochemical profile of replacement ewe lambs}

The effects of early feed restriction on biochemical profile during the artificial rearing $\left(1^{\text {st }}\right.$ month) and replacement periods (months $5^{\text {th }}$ and $7.5^{\text {th }}$ of life) are presented 
in Table 5. Several parameters related to energy (e.g., NEFA, BHB, cholesterol, LDL), protein metabolism (e.g., creatinine, urea, and total protein), minerals (e.g., Mg) or antioxidant and anti-inflammatory conditions (e.g., PON and FRAP) were either no modified or significantly reduced in the RES lambs only during the suckling period (e.g., PON and FRAP were reduced $22.5 \%$ and $19.3 \%$, respectively during the feed restriction period; $P<0.05$ for the interaction between treatment and day). However, albumin and GGT reductions persisted in RES ewe lambs several months after the end of the restriction period. No significant changes were observed in the rest of parameters of the biochemical profile (e.g., haptoglobin, ceruloplasmin, ROM, myeloperoxidase, SOD, Ca, Zn, retinol, tocopherol, AST, total bilirubin, glucose, insulin, globulin, HDL and triglycerides).

\section{Discussion}

In humans it has been observed a secondary immunodeficiency attributable to the poor nutritional status of undernourished children (Bourke et al., 2016). Accordingly, the reduction of submucosa thickness in the ileum (where iPP are located) of the RES lambs, together with the decreased staining intensity of M-cells, probably related to a reduced M-cell function (e.g., antigen uptake from the gastrointestinal tract; Mabbot et al., 2013; Prims et al., 2017) might have impacted negatively Peyer's patches maturation in the early feed restricted lambs (Rios et al., 2016).

On the other hand Manhart et al. (2000) mentioned that B lymphocytes of Peyer's patches may be more resistant to malnutrition than other immune cells. Accordingly, Rho et al. (2017) detected an increased frequency of long-lived plasma cells which can secrete large volumes of $\operatorname{IgA}$ in the small intestinal lamina propria of mice under severe protein-energy malnutrition (PEM) conditions. In addition, Beatty et al. (1983) also 
reported an enhanced synthesis of $\operatorname{sig} \mathrm{A}$ in duodenal mucosal biopsies from children with acute kwashiorkor (PEM), whereas others have observed that the transport of IgA through the epithelium can be increased by inflammatory (IFN- $\gamma$ ) and stress conditions (Reyna-Garfias et al., 2010). All these results seem to be in agreement with the higher levels of ileal sIgA observed in the RES lambs. It must be stated, however, that this would not be in contradiction with the reduced counts of B-cells observed in these RES lambs detected by both, flow cytometry (where only numerically lower values of CD21 ${ }^{+}$ were observed) and immunohistochemistry analysis, since not all the B-cells are differentiated into IgA-secreting plasma cells (Rios et al., 2016).

Furthermore, all the parameters measured by flow cytometry that were related to $\mathrm{T}$ lymphocytes $\left(\mathrm{CD}^{+}, \mathrm{CD}^{+}, \mathrm{WC1}^{+}\right)$at ileal level were increased in the RES group. Also numerically higher values of $\mathrm{T}$ cells could be observed by immunohistochemistry in early feed restricted lambs. Contrarily Fló et al. (1993 and 1994) described that B-cell and T-cell maturation were delayed in the GALT of 28 days undernourished rats. Nevertheless, in accordance with our results Campbell et al. (2003) and Amadi et al. (2009) found that $\mathrm{T}$ cells infiltrating the lamina propria rose and $\mathrm{B}$ cell numbers decreased in malnourished African children, whereas Márquez et al. (2000) also observed an increase in the number of $\mathrm{T}$ cells in the gut lamina propia and in the epithelium of rats fed a protein-free diet. Together all these data refute a generalized reduction in immune responsiveness caused by suboptimal nutrition, supporting instead a model of phenotypic plasticity in mucosal immunity that responds to nutrient availability, age, timing or severity of undernutrition (Bourke et al., 2016). However, the age of the lambs and the lack of nutrients during the early life make our study more comparable to those found in malnourished African children (Campbell et al., 2003; Amadi et al., 2009). 
In any case, the ileal down-regulation of genes encoding anti-inflammatory cytokines (IL-4, IL-10 and TGF- $\beta$ ), together with the significant upper transcription of IFN- $\gamma$ seemed to indicate a pro-inflammatory condition in the small intestine of RES lambs. These results are, again, in accordance with Campbell et al. (2003) and Amadi et al. (2009), who reported a Th1-dominated response in the small bowel of malnourished children, with a decrease of TGF- $\beta$ expression and an up-regulated expression of IFN- $\gamma$. Regarding ruminants, a previous study (Frutos et al., 2018) describing the long-term effects of early feed restriction during the fattening phase of lambs (once re-feeding was restored) suggested a relationship between increments of Prevotella spp. (concomitant with associated decreases in Bifidobacterium spp.) and pro-inflammatory conditions at ileal level. However, although a similar trend could be observed in the present study, our ileal samples were collected early during the restriction phase, which probably prevented the observation of significant changes in the relative abundances of Prevotella spp. or Bifidobacterium spp. in the RES lambs. Moreover, in agreement with Sun et al. (2001), Gomes de Morais et al. (2017), Da Costa et al. (2017) and Frutos et al. (2018) a down-regulation of some TLRs [pattern-recognition receptors of pathogenassociated molecular patterns located in several cell types such us macrophages, $\mathrm{T}$ and B cells or non-immune cells] was observed in RES lambs, which has been suggested as a mechanism implemented to keep the homeostasis at intestinal level (Zhang and Ghosh, 2002; Malmuthuge et al., 2012; Villena et al., 2014). In any case, all these alterations in the gut could be, at least, partially responsible for the reduced animal performance of RES lambs.

The decreased energy and protein intake of RES lambs during the suckling period might have impaired liver functionality as suggested by the lower levels of albumin, GGT, FRAP, PON and cholesterol observed for the RES lambs during the first month 
of life (Bionaz et al., 2007, Bertoni and Trevisi, 2013). Moreover, the lower levels of NEFA and BHB in the RES lambs during the suckling period, together with the lower total fat depots of these animals (292 vs. $111 \mathrm{~g}$ for ADL and RES lambs, respectively; $\mathrm{SED}=4.81 ; P<0.001)$ suggest that adipose tissue was exhausted after a month of MR restriction. In addition, the lower levels of creatinine in the pre-weaned RES lambs seem to be indicating a reduced muscle mass in absolute terms (Agenäs et al., 2006). Most of these effects on the biochemical profile disappeared, at least partially (no significant effects, but numerically different values during the $5^{\text {th }}$ and $7.5^{\text {th }}$ months of life), once the refeeding conditions were restored, whereas the rest of biochemical parameters (e.g., haptoglobin, ceruloplasmine, ROM, myeloperoxidase, SOD, Ca, Zn, retinol, tocopherol, AST, total bilirubin, glucose, insulin, globulin, HDL and triglycerides) were not modified at any time. However, the lower values of albumin and GGT in the RES lambs are remarkable because they persisted several months after the feed restriction period was ended, suggesting negative residual effects on liver functionality which might have further impaired animal performance along the replacement phase. It must be considered that GGT enables the metabolism of antioxidants, inflammatory molecules, drug metabolites, glutathione and glutathionylated xenobiotics (Koenig and Seneff, 2015). Therefore, the lower levels of GGT observed in the RES ewe lambs along the whole experimental period might be associated to several indicators of intracellular stress and inflammatory response (e.g., phosphatidylserine compounds and prostaglandin E2-biotin) that were over accumulated in the plasma of these animals according to their metabolome profile published previously elsewhere (Santos et al., 2018).Moreover, other studies have shown that malnutrition is related to oxidative stress conditions as a consequence of chronic inflammation events (Ece et al., 2007). In the present study a transitory 
imbalance in the antioxidant status during the suckling period could be observed in the pre-weaned RES lambs (e.g., lower FRAP and PON values), which also manifested proinflammatory conditions at ileal level. However, the lack of significant differences in the positive acute-phase proteins involved in inflammation (e.g., haptoglobin and ceruloplasmin) or in those parameters related to metabolic disorders such as insulin resistance (e.g., glucose and insulin) differ from those results previously observed in early feed restricted fattening lambs (Frutos et al., 2018b). This apparent contradiction might be explained by the different diets administered during the refeeding period in each experiment: whilst the replacement ewes were fed a TMR rich in fibre, the fattening lambs were fed an acidogenic diet (e.g., rich in cereals and carbohydrates) which together with the pro-inflammatory conditions promoted by early feed restriction might have compromised the health status under stressful diet conditions.

\section{Conclusions}

In conclusion, under the conditions of the present study our results suggest that the reduced animal performance observed in early feed restricted ewe lambs is associated with pro-inflammatory conditions in the gut and a persistent impaired liver functionality after the period of feed restriction.

\section{Acknowledgements}

This work was supported by the Spanish Ministry of Economy, Industry and Competitiveness (MINECO, AGL2014-54124R). Javier Frutos was supported by CSIC (Proyecto Intramural Especial; Project 201540E084) and Ayudas Puente Formativas (Universidad de León) with a training contract. Alba Santos gratefully acknowledges 
receipt of a pre-doctoral grant from the Spanish Ministry of Education, Culture and Sport (MECD, FPU15/01630).

\section{References}

Agenäs, S., Heath, M.F., Nixon, R.M., Wilkinson, J.M., Phillips, C.J.C., 2006. Indicators of undernutrition in cattle. Anim. Welf. 15, 149-160.

Amadi, B., Fagbemi, A.O., Kelly, P., Mwiya, M., Torrente, F., Salvestrini, C., Day, R., Golden, M.H., Eklund, E.A., Freeze, H.H., Murch, S.H., 2009. Reduced production of sulfated glycosaminoglycans occurs in Zambian children with kwashiorkor but not marasmus. Am. J. Clin. Nutr. 89, 592-600. doi: 10.3945/ajen.2008.27092

Beatty, D.W., Napier, B., Sinclairsmith, C.C., McCabe, K., Hughes, E.J., 1983. Secretory IgA synthesis in Kwashiorkor. J. Clin. Lab. Immunol. 12, 31-36.

Bertoni, G., Trevisi, E., 2013. Use of the Liver Activity Index and other metabolic variables in the assessment of metabolic health in dairy herds. Vet. Clin. Food Anim. 29, 413-431. doi: 10.1016/j.cvfa.2013.04.004

Bionaz, M., Trevisi, E., Calamari, L., Librandi, F., Ferrari, A., Bertoni, G., 2007. Plasma paraoxonase, health, inflammatory conditions and liver function in transition dairy cows. J. Dairy Sci. 90, 1740-1750. doi: 10.3168/jds.2006-445

Bourke, C.D., Berkley, J.A., Prendergast, A.J., 2016. Immune dysfunction as a cause and consequence of malnutrition. Trends Immunol. 37, 386-398. doi: 10.1016/j.it.2016.04.003

Campbell, D.I., Murch, S.H., Elia, M., Sullivan, P.B., Sanyang, M.S., Jobarteh, B., Lunn, P.G., 2003. Chronic T cell-mediated enteropathy in rural west African children: Relationship with nutritional status and small bowel function. Pediatr. 
Res. 54, 306-311. doi: 10.1203/01.PDR.0000076666.16021.5E

Carro, M.D., Miller, E.L., 1999. Effect of supplementing a fibre basal diet with different nitrogen forms on ruminal fermentation and microbial growth in an in vitro semicontinuous culture system (RUSITEC). Br. J. Nutr. 82, 149-157. doi: $10.1017 / \mathrm{S} 0007114599001300$

Celi, P., Cowieson, A.J., Fru-Nji, F., Steinert, R.E., Kluenter, A.M., Verlhac, V., 2017. Gastrointestinal functionality in animal nutrition and health: New opportunities for sustainable animal production. Anim. Feed Sci. Technol. 234, 88-100. doi: 10.1016/j.anifeedsci.2017.09.012

Chandra, R.K., 1997. Nutrition and the immune system: an introduction. Am. J. Clin. Nutr. 66, 460S-463S. doi: 10.1093/ajcn/66.2.460S

Da Costa, T.B., De Morais, N.G., De Lira, J.M., De Almeida, T.M., Gonçalves-DeAlbuquerque, S.D., Pereira, V.R., De Paiva Cavalcanti, M., De Castro, C.M., 2017. Relation between neonatal malnutrition and gene expression: inflammasome function in infections caused by Candida albicans. Eur. J. Nutr. 56, 693-704. doi: 10.1007/s00394-015-1113-9

Ece, A., Gurkan, F., Celik, F., Bosnak, M., Yel, S., Balik, H., Erel, O., 2007. Paraoxonase, total antioxidant activity and peroxide levels in marasmic children: Relationships with leptin. Clin. Biochem. 40, 634-639. doi: 10.1016/j.clinbiochem.2007.03.001

Fló, J., Elias, F., Massouh, E., Roux, M.E., 1994. Impairment of B-cell and T-cell maturation in gut-associated lymphoid-tissues due to malnutrition during lactation. Dev. Comp. Immunol. 18, 543-555. doi: 10.1016/S0145$305 X(06) 80008-\mathrm{X}$ 
Fló, J., Massouh, E.J., Roux, M.E., 1993. Long term effects of malnutrition during lactation on GALT. Reg. Immunol. 5, 100-105.

Frutos, J., Andrés, S., Yáñez-Ruiz, D.R., Benavides, J., López, S., Santos, A., MartínezValladares, M., Rozada, F., Giráldez, F.J., 2018a. Early feed restriction of lambs modifies ileal epimural microbiota and affects immunity parameters during the fattening period. Anim. (in press). doi: 10.1017/S1751731118000836

Frutos, J., Andrés, S., Trevisi, E., Yáñez-Ruiz, D.R., López, S., Santos, A., Giráldez, F.J., 2018b. Early feed restriction programs metabolic disorders in fattening Merino lambs. Animals 2018, 8(6), 83; https://doi.org/10.3390/ani8060083.

Giráldez, F.J., Frutos, P., Lavín, P., Mantecón, A.R., 1999. Body composition changes and energy retention in milk-fed lambs undergoing energy restriction. Small Rumin. Res. 31, 127-133. doi: 10.1016/S0921-4488(98)00129-1

Gomes de Morais, N., Barreto da Costa, T., Bezerra de Lira, J.M., da Cunha Gonçalves de Albuquerque, S., Alves Pereira, V.R., de Paiva Cavalcanti, M., Machado Barbosa de Castro, C.M., 2017. TLR and NLRP3 inflammasome expression deregulation in macrophages of adult rats subjected to neonatal malnutrition and infected with methicillin-resistant Staphylococcus aureus. Nutrition 33, 174-180. doi: 10.1016/j.nut.2016.06.005

Hirsch, F.R., Varella-Garcia, M., Bunn, P.A., Di Maria, M.V., Veve, R., Bremnes, R.M., Baron, A.E., Zeng, C., Franklin, W.A., 2003. Epidermal growth factor receptor in non-small-cell lung carcinomas: Correlation between gene copy number and protein expression and impact on prognosis. J. Clin. Oncol. 21, 37983807. doi: 10.1200/JCO.2003.11.069

Koenig, G., Seneff, S., 2015. Gamma-glutamyltransferase: a predictive biomarker of cellular antioxidant inadequacy and disease risk. Disease Markers Article ID 
818570. doi: $10.1155 / 2015 / 818570$

Mabbott, N.A., Donaldson, D.S., Ohno, H., Williams, I.R., Mahajan, A., 2013. Microfold (M) cells: important immunosurveillance posts in the intestinal epithelium. Mucosal Immunol. 6, 666-677. doi: 10.1038/mi.2013.30

Malmuthuge, N., Li, M., Fries, P., Griebel, P.J., Guan, L.L., 2012. Regional and age dependent changes in gene expression of Toll-like receptors and key antimicrobial defence molecules throughout the gastrointestinal tract of dairy calves. Vet. Immunol. Immunopathol. 146, 18-26. doi: 10.1016/j.vetimm.2012.01.010

Manhart, N., Vierlinger, K., Bergmeister, H., Boltz-Nitulescu, G., Spittler, A., Roth, E., 2000. Influence of short-term protein malnutrition of mice on the phenotype and costimulatory signals of lymphocytes from spleen and Peyer's patches. Nutrition 16, 197-201. doi: 10.1016/S0899-9007(99)00279-8

Márquez, M.G., Galeano, A., Olmos, S., Roux, M.E., 2000. Flow cytometric analysis of intestinal intraepithelial lymphocytes in a model of immunodeficiency in Wistar rats. Cytometry 41, 115-122. doi: 10.1002/1097-0320(20001001)41:2<115::AIDCYTO6>3.0.CO;2-5

NRC (National Research Council), 1985. Nutrient requirements of sheep, sixth ed. National Academy Press, Washington D.C.

Prims, S., Pintens, N., Vergauwen, H., Van Cruchten, S., Van Ginneken, C., Casteleyn, C., 2017. Effect of artificial rearing of piglets on the volume densities of M cells in the tonsils of the soft palate and ileal Peyer's patches. Vet. Immunol. Immunop. 184, 1-7. doi: 10.1016/j.vetimm.2016.12.009

Reyna-Garfias, H., Miliar, A., Jarillo-Luna, A., Rivera-Aguilar, V., Pacheco-Yépez, J., Baeza, I., Campos-Rodríguez, R., 2010. Repeated restraint stress increases IgA concentration in rat small intestine. Brain Behav. Immun. 24, 110-118. doi: 
10.1016/j.bbi.2009.09.005

Rho, S., Kim, H., Shim, S.H., Lee, S.Y., Kim, M.J., Yang, B.G., Jang, M.H., Hail, B.W., Song, M.K., Czerkinsky, C., Kim, J.O., 2017. Protein energy malnutrition alters mucosal IgA responses and reduces mucosal vaccine efficacy in mice. Immunol. Lett. 190, 247-256. doi: 10.1016/j.imlet.2017.08.025

Rios, D., Wood, M.B., Li, J., Chassaing, B., Gewirtz, A.T., Williams, I.R., 2016. Antigen sampling by intestinal $\mathrm{M}$ cells is the principal pathway initiating mucosal IgA production to commensal enteric bacteria. Mucosal Immunol. 9, 907-916. doi: $10.1038 / \mathrm{mi} .2015 .121$

Santos, A., Giráldez, F.J., Valdés, C., Trevisi, E., Lucini, L., Frutos, J., Andrés, S., 2018. Milk replacer restriction during the early life impairs the live body weight and progesterone patterns of ewe lambs during the replacement period. J. Dairy Sci. [In press].

Schäff, C.T., Gruse, J., Maciej, J., Mielenz, M., Wirthgen, E., Hoeflich, A., Schmicke, M., Pfuhl, R., Jawor, P., Stefaniak, T., Hammon, H.M., 2016. Effects of feeding milk replacer ad libitum or in restricted amounts for the first five weeks of life on the growth, metabolic adaptation, and immune status of newborn calves. PLoS One 11, e0168974. doi: 10.1371/journal.pone.0168974

Sun, D., Muthukumar, A.R., Lawrence, R.A., Fernandes, G., 2001. Effects of calorie restriction on polymicrobial peritonitis induced by cecum ligation and puncture in young C57BL/6 mice. Clin. Diagn. Lab. Immunol. 8, 1003-1011. doi: 10.1128/CDLI.8.5.1003-1011.2001

Villena, J., Aso, H., Kitazawa, H., 2014. Regulation of toll-like receptors-mediated inflammation by immunobiotics in bovine intestinal epitheliocytes: role of signaling pathways and negative regulators. Front. Immunol. 5, 421. doi: 


\subsection{9/fimmu.2014.00421}

Zhang, G.L., Ghosh, S., 2002. Negative regulation of toll-like receptor-mediated signaling by Tollip. J. Biol. Chem. 277, 7059-7065. doi: 10.1074/jbc.M109537200 
Table 1. Ingredients and chemical composition of the commercial lamb milk replacer

\section{Ingredients, $\mathrm{g} / \mathrm{kg}$}

Skim milk powder

Milk whey powder

Vegetable oil (cocoa)

Animal fat (pork lard)

Whey protein powder

Hydrolysed wheat protein

Yeast/sodium bicarbonate /Dextrose

PreVIT mineral $^{\mathrm{a}}$

Chemical composition, $\mathrm{g} / \mathrm{kg}$ dry matter

Dry matter, $\mathrm{g} / \mathrm{kg}$

Crude protein

Ether extract

Ash

Metabolisable energy, $\mathrm{kcal} / \mathrm{kg} \mathrm{DM}$

${ }^{a}$ Provided per kg milk replacer: vitamin A, 80,000 IU; vitamin $\mathrm{D}_{3}, 4250 \mathrm{IU}$; iron, $40 \mathrm{mg}$; cobalt, $0.2 \mathrm{mg}$; copper, $5 \mathrm{mg}$; manganese, $25 \mathrm{mg}$; zinc, $30 \mathrm{mg}$; selenium, $0.2 \mathrm{mg}$ 
Table 2. Ingredients and chemical composition of the total mixed ration administered to replacement lambs

\begin{tabular}{lc}
\hline Ingredients, g/kg & 360 \\
Barley & 160 \\
Lucerne & 157 \\
Barley straw & 133 \\
Vetch & 50 \\
Molasses (sugar cane) & 50 \\
Corn & 43 \\
Sunflower & 30 \\
Soybean meal 44 & 17 \\
Vitamins and minerals & 53
\end{tabular}

Chemical composition, g/kg dry matter

$\begin{array}{lr}\text { Dry matter, } \mathrm{g} / \mathrm{kg} & 892\end{array}$

$\begin{array}{ll}\text { Neutral detergent fibre (aNDF) }^{\mathrm{a}} & 355\end{array}$

$\begin{array}{ll}\text { Acid detergent fibre (ADF) } & 215\end{array}$

$\begin{array}{ll}\text { Crude protein } & 125\end{array}$

$\begin{array}{ll}\text { Ash } & 75\end{array}$

Metabolisable energy, $\mathrm{kcal} / \mathrm{kg} \mathrm{DM} 2303$

${ }^{a}$ NDF was assayed with a heat stable amylase and expressed inclusive of residual ash 
Table 3. Lymphocyte counts by flow cytometry, morphometric analysis, immunohistochemistry, and secretory immunoglobulin $\mathrm{A}(\operatorname{sg} \mathrm{A})$ production in the ileum of pre-weaned lambs being fed ad libitum (ADL) o restricted (RES) during the artificial rearing period.

Lymphocytes, $\%^{\mathrm{b}}$

$\mathrm{CD} 4^{+}$
$\mathrm{CD} 8^{+}$
$\mathrm{WC}^{+}$(gamma-delta T cells)
$\mathrm{CD} 21^{+}$
$\mathrm{CD} 45 \mathrm{R}^{+}$
$\mathrm{CD} 4^{+} / \mathrm{CD} 8^{+}$

Ileal thickness, $\mu \mathrm{m}$

Mucosa

Submucosa

Muscular

Lymphocytes, number per field $40 \times$

AD
6.1
8.1
6.4
18.8
18.3
0.77

ADL

RES

SED $^{\mathrm{a}}$

$P$-value

6.1

9.9

1.764

0.049

8.1

13.7

2.587

0.047

6.4

9.3

1.143

0.021

18.8

12.6

3.763

0.120

18.3

14.2

4.213

0.347

0.77

0.81

0.118

0.724

$\begin{array}{rrrr}980 & 958 & 61.0 & 0.717 \\ 1023 & 757 & 97.0 & 0.016 \\ 178 & 162 & 21.4 & 0.487\end{array}$

$\mathrm{CD} 20^{+}$(B cells)

$\mathrm{CD} 3^{+}(\mathrm{T}$ cells $)$

$\begin{array}{rrrr}3.52 & 2.34 & 0.368 & 0.006 \\ 176 & 204 & 16.6 & 0.138\end{array}$

\section{$\mathrm{CK18}^{+}$(M-cells), $\%^{\mathrm{c}}$}

High positive

Medium positive

3.77

1.91

6.064

0.171

16.0

11.0

3.75

0.238

51.9

45.2

4.65

0.221

28.4

41.9

6.30

0.065

Negative

95.1

72.9

11.00

0.083

$\mathbf{s I g A}, \mathrm{pg} / \mu \mathrm{g}$ total protein

10.2

14.5

1.70

0.023

\footnotetext{
${ }^{a} \mathrm{SED}$, standard error of the difference

${ }^{\mathrm{b}}$ Percentage of positive stained cells in sample populations of 10,000 individual cells

${ }^{c}$ Percentage of positive labelled area in the epithelial cells of ileal Peyer's patches dome

d "Histo" score (from 0 to 300 ), higher values indicating higher-intensity labelled area of epithelial cells according to Hirsch et al. (2003).
} 
Table 4. Cytokines and toll-like receptors (TLRs) ${ }_{\mathrm{m}}$ RNA expression in ileal mucosa of pre-weaned lambs being fed ad libitum (ADL) o restricted (RES) during the artificial rearing period.

ADL RES $\quad$ SED $^{\text {a }} P$-value

Cytokines, $\Delta \mathrm{Cq}^{\mathrm{b}}$

$\begin{array}{lcccc}\text { IFN- }^{\mathrm{c}} & 10.84 & 9.14 & 0.683 & 0.039 \\ \text { TGF- }^{\mathrm{d}} & 3.50 & 4.03 & 0.152 & 0.005 \\ \text { IL-4 }^{\mathrm{e}} & 11.89 & 12.88 & 0.506 & 0.081 \\ \text { IL-10 }^{\mathrm{f}} & 8.76 & 9.39 & 0.217 & 0.016\end{array}$

TLRs, $\Delta \mathrm{Cq}$

$\begin{array}{lllll}\text { TLR }_{1} & 8.00 & 8.70 & 0.291 & 0.036 \\ \text { TLR }_{2} & - & - & - & - \\ \text { TLR } & & 10.07 & 0.210 & 0.710 \\ \text { TLR }_{4} & 10.15 & 7.66 & 0.236 & 0.585 \\ \text { TLR }_{5} & 7.52 & 16.28 & 0.742 & 0.558 \\ \text { TLR }_{6} & 16.74 & 11.01 & 0.262 & 0.015 \\ \text { TLR }_{7} & 10.21 & 8.88 & 0.183 & 0.003 \\ \text { TLR }_{8} & 8.12 & 9.01 & 0.175 & 0.313 \\ \text { TLR }_{9} & 9.22 & 7.43 & 0.289 & 0.037 \\ \text { TLR }_{10} & 6.73 & 5.11 & 0.408 & 0.097\end{array}$

${ }^{\mathrm{a}} \mathrm{SED}$, standard error of the difference

${ }^{\mathrm{b}} \mathrm{Cq}$, quantification cycle. $\Delta \mathrm{Cq}=\mathrm{Cq}$ (cytokines or TLRs) $-\mathrm{Cq}(\beta$-actin). Lower $\mathrm{Cq}$ represents higher ${ }_{\mathrm{m}} \mathrm{RNA}$ abundance level

${ }^{\mathrm{c}} \mathrm{IFN}-\gamma$, interferon gamma

${ }^{\mathrm{d}}$ TGF- $\beta$, transforming growth factor beta

${ }^{\mathrm{e}} \mathrm{IL}-4$, interleukin 4

${ }^{\mathrm{f}} \mathrm{IL}-10$, interleukin 10 
Table 5. Biochemical parameters of lambs fed ad libitum (ADL) or restricted (RES) during the artificial rearing period.

\begin{tabular}{|c|c|c|c|c|c|c|c|c|c|c|c|}
\hline & \multicolumn{2}{|c|}{$1^{\text {st }}$ month } & \multicolumn{2}{|c|}{$5^{\text {th }}$ month } & \multicolumn{2}{|c|}{$\underline{7.5}^{\text {th }}$ month } & \multirow[b]{2}{*}{ SED $_{1}^{1}$} & \multirow[b]{2}{*}{$\mathbf{S E D}_{2}^{2}$} & \multicolumn{3}{|c|}{ P-value } \\
\hline & $\mathbf{A D L}$ & RES & $\mathbf{A D L}$ & RES & $\overline{\mathbf{A D L}}$ & RES & & & $\mathbf{T}^{3}$ & $\mathbf{D}^{4}$ & $\mathbf{T} * \mathbf{D}^{5}$ \\
\hline Haptoglobin, g/L & 0.510 & 0.556 & 0.272 & 0.402 & 0.171 & 0.387 & 0.1701 & 0.1772 & 0.450 & 0.341 & 0.893 \\
\hline Ceruloplasmine, $\mu \mathrm{mol} / \mathrm{L}$ & 3.86 & 4.24 & 2.70 & 2.97 & 2.53 & 2.76 & 0.445 & 0.308 & 0.514 & $<0.001$ & 0.967 \\
\hline $\mathrm{BHB}^{6}, \mathrm{mmol} / \mathrm{L}$ & $0.574^{\mathrm{c}}$ & $0.147^{\mathrm{a}}$ & $0.518^{\mathrm{c}}$ & $0.523^{c}$ & $0.279^{b}$ & $0.282^{b}$ & 0.0402 & 0.0425 & 0.002 & $<0.001$ & $<0.001$ \\
\hline $\mathrm{PON}^{7}, \mathrm{U} / \mathrm{L}$ & $173^{\mathrm{b}}$ & $134^{\mathrm{a}}$ & $159^{b}$ & $149^{\mathrm{ab}}$ & $166^{\mathrm{b}}$ & $152^{\mathrm{b}}$ & 12.5 & 4.86 & 0.106 & 0.455 & 0.012 \\
\hline $\mathrm{ROM}^{8}, \mathrm{mg} / 100 \mathrm{Ml}$ & 20.5 & 20.8 & 15.3 & 16.3 & 14.3 & 15.3 & 1.74 & 1.24 & 0.672 & $<0.001$ & 0.951 \\
\hline Myeloperoxidase, U/L & 550 & 486 & 470 & 481 & 532 & 495 & 49.4 & 48.8 & 0.550 & 0.630 & 0.747 \\
\hline $\mathrm{FRAP}^{9}, \mu \mathrm{mol} / \mathrm{L}$ & $155^{\mathrm{b}}$ & $125^{\mathrm{a}}$ & $134^{\mathrm{a}}$ & $133^{\mathrm{a}}$ & $134^{\mathrm{a}}$ & $131^{\mathrm{a}}$ & 5.77 & 5.32 & 0.065 & 0.289 & 0.018 \\
\hline $\mathrm{SOD}^{10}, \mathrm{U} / \mathrm{L}$ & 1.03 & 0.962 & 1.25 & 1.22 & 1.34 & 1.46 & 0.125 & 0.086 & 0.952 & $<0.001$ & 0.500 \\
\hline $\mathrm{Ca}, \mathrm{mmol} / \mathrm{L}$ & 2.84 & 2.79 & 2.91 & 2.84 & 2.83 & 2.84 & 0.027 & 0.0327 & 0.151 & 0.160 & 0.483 \\
\hline $\mathrm{Mg}, \mathrm{mmol} / \mathrm{L}$ & $1.031^{\mathrm{c}}$ & $0.852^{\mathrm{a}}$ & $0.931^{\mathrm{b}}$ & $0.906^{\mathrm{b}}$ & $0.907^{\mathrm{b}}$ & $0.911^{\mathrm{b}}$ & 0.0166 & 0.0161 & $<0.001$ & 0.130 & $<0.001$ \\
\hline $\mathrm{Zn}, \mathrm{mmol} / \mathrm{L}$ & 22.6 & 20.3 & 17.2 & 15.8 & 18.3 & 17.3 & 1.13 & 1.15 & 0.172 & $<0.001$ & 0.852 \\
\hline Retinol, ug/100 mL & 22.0 & 22.5 & 53.3 & 45.2 & 58.0 & 49.1 & 3.92 & 3.21 & 0.174 & $<0.001$ & 0.286 \\
\hline Tocopherol, ug/mL & $1.16^{\mathrm{b}}$ & $1.42^{\mathrm{b}}$ & $0.782^{\mathrm{a}}$ & $0.700^{\mathrm{a}}$ & $0.681^{\mathrm{a}}$ & $0.620^{\mathrm{a}}$ & 0.115 & 0.071 & 0.732 & $<0.001$ & 0.036 \\
\hline $\mathrm{AST}^{11}, \mathrm{U} / \mathrm{L}$ & 90.7 & 85.0 & 139 & 127 & 141 & 127 & 6.40 & 5.86 & 0.116 & $<0.001$ & 0.776 \\
\hline $\mathrm{GGT}^{12}, \mathrm{U} / \mathrm{L}$ & 90.4 & 74.2 & 58.3 & 51.1 & 62.1 & 52.3 & 3.89 & 2.40 & 0.009 & $<0.001$ & 0.170 \\
\hline Total bilirubin, $\mu \mathrm{mol} / \mathrm{L}$ & 2.65 & 2.37 & 0.77 & 0.86 & 0.62 & 0.56 & 0.314 & 0.381 & 0.796 & $<0.001$ & 0.887 \\
\hline Creatinine, $\mu \mathrm{mol} / \mathrm{L}$ & $80.8^{c}$ & $67.9^{\mathrm{a}}$ & $76.7^{\mathrm{bc}}$ & $73.3^{b}$ & $78.9^{\mathrm{bc}}$ & $74.0^{\mathrm{b}}$ & 2.37 & 1.55 & 0.007 & 0.382 & 0.008 \\
\hline Glucose, mmol/L & 4.64 & 5.40 & 5.63 & 5.24 & 5.00 & 5.13 & 0.196 & 0.236 & 0.411 & 0.166 & 0.064 \\
\hline Insulin, ng/L & 96.2 & 105 & 297 & 199 & 265 & 270 & 48.03 & 59.73 & 0.563 & 0.032 & 0.313 \\
\hline Urea, mmol/L & $7.29^{\mathrm{bc}}$ & $4.63^{\mathrm{a}}$ & $6.95^{\mathrm{b}}$ & $6.12^{b}$ & $8.03^{c}$ & $7.25^{\mathrm{bc}}$ & 0.459 & 0.411 & 0.005 & $<0.001$ & 0.042 \\
\hline Protein, g/L & 61.1 & 55.7 & 70.1 & 68.0 & 70.6 & 69.2 & 1.24 & 1.20 & 0.028 & $<0.001$ & 0.211 \\
\hline Albumin, $g / L$ & $33.6^{\mathrm{b}}$ & $30.4^{\mathrm{a}}$ & $37.1^{\mathrm{d}}$ & $35.8^{c}$ & $36.7^{\mathrm{cd}}$ & $36.0^{\mathrm{c}}$ & 0.39 & 0.36 & $<0.001$ & $<0.001$ & 0.005 \\
\hline Globulin, g/L & 27.6 & 25.3 & 33.1 & 32.3 & 33.8 & 33.3 & 1.12 & 1.10 & 0.297 & $<0.001$ & 0.713 \\
\hline Cholesterol, mmol/L & $2.78^{\mathrm{c}}$ & $2.17^{\mathrm{b}}$ & $1.93^{\mathrm{a}}$ & $1.71^{\mathrm{a}}$ & $1.88^{\mathrm{a}}$ & $1.80^{\mathrm{a}}$ & 0.123 & 0.078 & 0.022 & $<0.001$ & 0.005 \\
\hline $\mathrm{LDL}^{13}, \mathrm{mmol} / \mathrm{L}$ & $0.561^{\mathrm{b}}$ & $0.298^{\mathrm{a}}$ & $0.574^{\mathrm{b}}$ & $0.457^{\mathrm{b}}$ & $0.493^{\mathrm{b}}$ & $0.461^{\mathrm{b}}$ & 0.040 & 0.028 & 0.002 & 0.016 & $<0.001$ \\
\hline $\mathrm{HDL}^{14}, \mathrm{mmol} / \mathrm{L}$ & 1.46 & 1.43 & 0.989 & 0.913 & 1.03 & 0.987 & 0.090 & 0.048 & 0.577 & $<0.001$ & 0.891 \\
\hline $\mathrm{NEFA}^{15}, \mathrm{~g} / \mathrm{L}$ & $1.13^{\mathrm{c}}$ & $0.486^{\mathrm{b}}$ & $0.117^{\mathrm{a}}$ & $0.123^{\mathrm{a}}$ & $0.136^{\mathrm{a}}$ & $0.182^{\mathrm{a}}$ & 0.056 & 0.069 & 0.002 & $<0.001$ & $<0.001$ \\
\hline
\end{tabular}




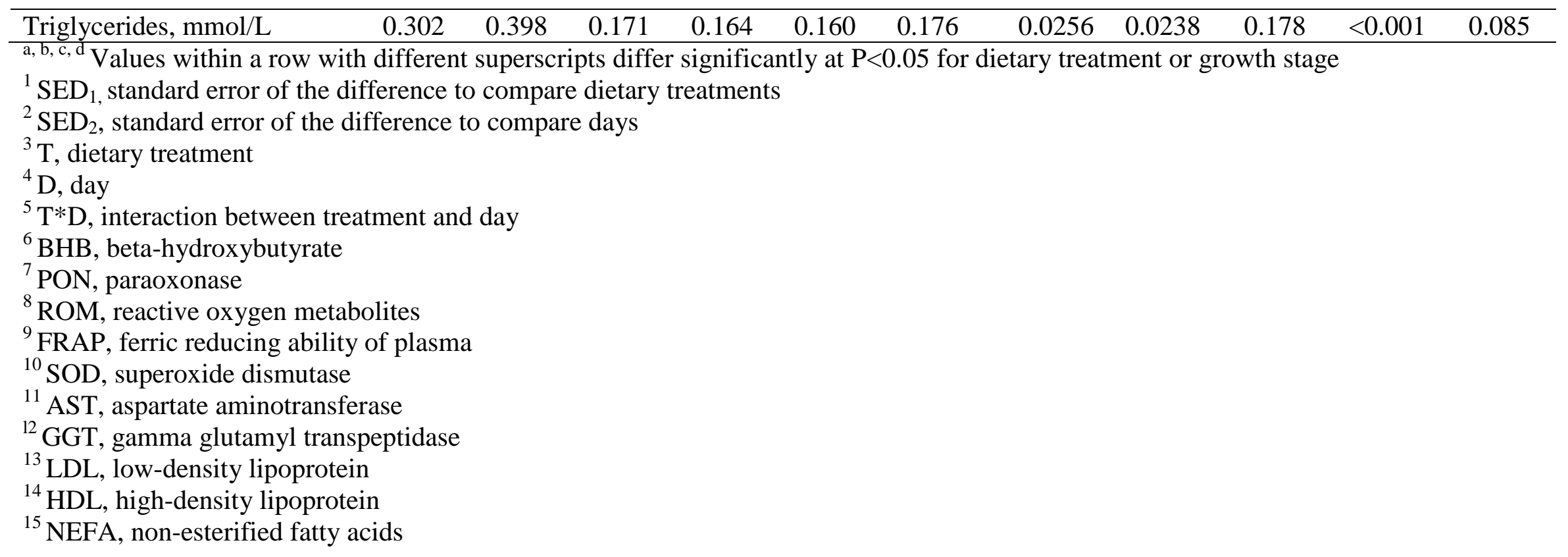




\section{Figure captions}

Fig. 1. Relative quantitation compared to ad libitum lambs (ADL) of $16 \mathrm{~S}$ rRNA copy numbers of microbial groups attached to the ileal mucosa after early feed restriction (RES) during the suckling period. Fold-changes for specific amplicon groups were calculated as the $\log _{2}$ ratio of normalized abundances. No significant differences $(P>0.05)$ calculated using Tukey's method (SAS) were observed.

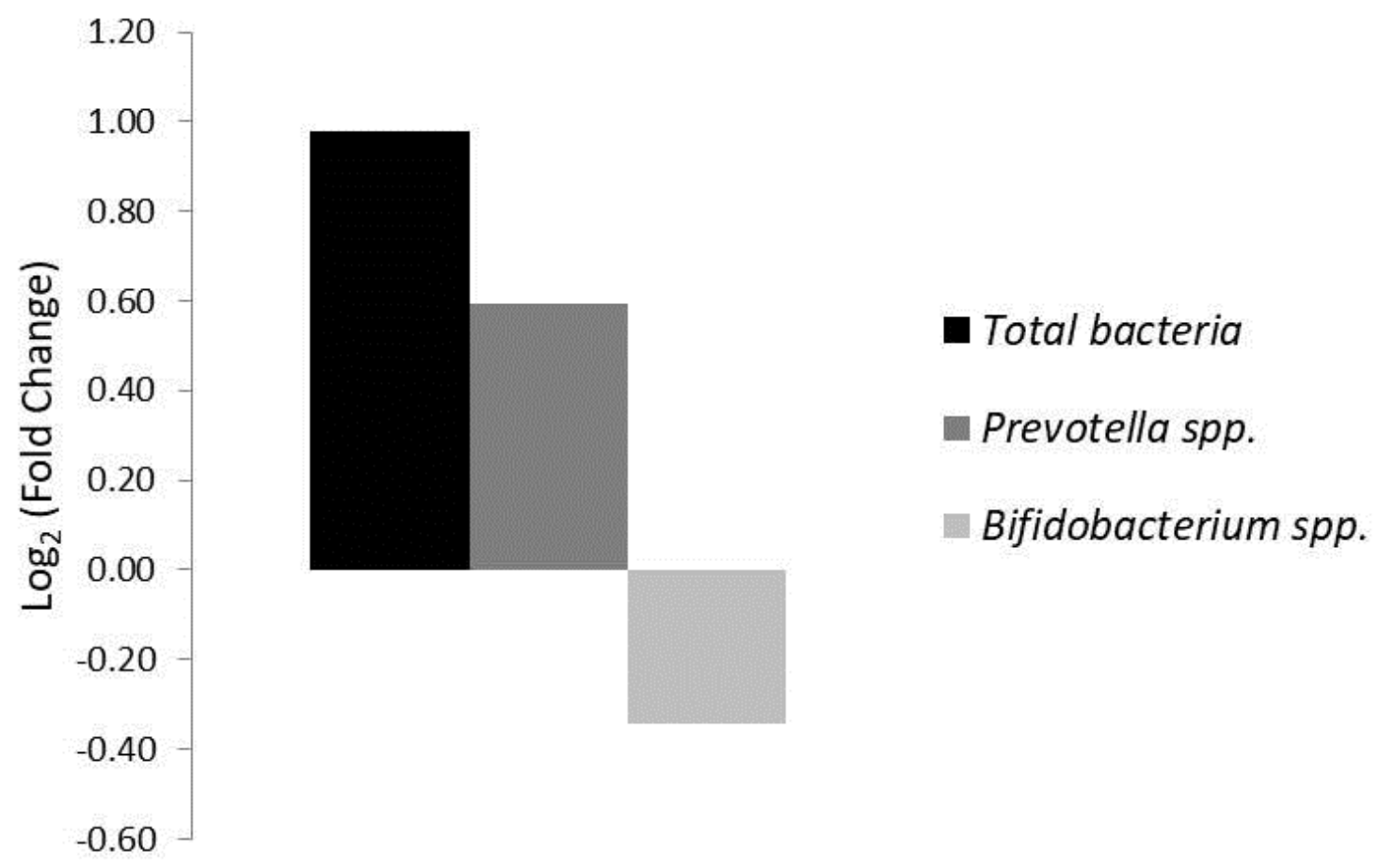

Fig. 2. Thickness of submucosa layer (arrows) in ileal segments of ad libitum (ADL) (A) and early feed restricted (RES) lambs (B). B cells labelled in the lamina propria of ADL (C) and RES lambs (D). T cells labelled in the lamina propria of ADL (E) and RES animals (F). Cytokeratin 18 labelling (M-cells) in Peyer's patches domes of ADL $(\mathrm{G})$ and RES lambs $(\mathrm{H})$. 